\title{
Measuring Good Architecture: Long life, loose fit, low energy
}

\author{
By Craig Langston ${ }^{1}$
}

\begin{abstract}
Good architecture is something that we all seek, but which is difficult to define. Sir Alexander John Gordon, in his role as President of the Royal Institute of British Architects, defined 'good architecture' in 1972 as buildings that exhibit 'long life, loose fit and low energy'. These characteristics, nicknamed by Gordon as the 3L Principle, are measurable. Furthermore, life cycle cost (LCC) provides a method for accessing the economic contribution or burden created by buildings to the society they aim to serve. Yet there is no research available to investigate the connection, if any, between 3L and LCC. It might be hypothesised that buildings with a high 3L index have a low LCC profile. If this is true, then LCC may be able to be used to assess ' $g o o d$ architecture'. This paper uses a case study methodology to assess the durability, adaptability and sustainability of 22 projects that have won architectural design awards. The $3 \mathrm{~L}$ criteria can bemeasured and compared with average LCC per square metre using a long time horizon. The research is significant in that it tests a process to objectively assess what is commonly intangible and to determine if LCC is a suitable predictor of 'good architecture'.
\end{abstract}

Keywords: Sustainable urbanism, architecture, built environment

\section{Introduction}

Sir Alexander John Gordon (1917-1999) was a Welsh architect, born in Ayr (Scotland) and raised in Swansea and Cardiff. He had his own practice, Alex Gordon and Partners, and was visiting professor at the Bartlett School of Architecture, University College London. He served as president of the Royal Institute of British Architects (RIBA) from 1971-1973. It was during this time he wrote a paper on the future shape of architecture, in which he argued that buildings should be designed for long life, loose fit and low energy (Gordon, 1972). While his peers did not immediately embrace this idea, over time it became a mantra that potentially can define good architecture and its role in modern society.

The idea of building for permanence, yet incorporating flexibility to accommodate future change and minimising energy footprint throughout its physical life, is surely the ultimate holistic objective for the architecture profession (Murray, 2011). Today these objectives may be summarised as durable, adaptable and sustainable. Good architecture should reflect these properties, and not merely be works of public art or a monument to their designers, technological prowess or the financial wealth of their owner. Good architecture lies in the care with which buildings are designed to provide long-term 
benefits to the society they serve, and transcend the utilitarian and the fashionable in favour of performance and legacy.

The sustainable development movement arose more than a decade after what Gordon coined the 3L Principle, and has continued to gain prominence, particularly in the developed world. Yet the focus has been on green building, with less consideration being given to durability and adaptability. Jacobs (1961) made the remark that the greenest buildings are the ones we already have. For this to be true, it implies that their original design must have considered issues of longevity and flexibility else they would not have anything still to offer in the changing world within which we live. Good architecture must stand the test of time.

No one has ever demonstrated that long life, loose fit and low energy are mutually exclusive. Nor has it been proven that beauty and performance are incompatible. On the contrary, our greatest buildings should possess all these fundamentals, as well as reflect the culture and achievements of their time. Good architecture should inspire, challenge norms and encourage opinion. Are we able to recognise today what will be understood to be good architecture well into the future? How can we measure good architecture at the outset?

Sustainable development needs to embody Gordon's 3L Principle and treat durability, adaptability and sustainability as equally important. A zero carbon building with a short life span and no consideration of alternative uses after its original function becomes obsolete is arguably only a minor contribution to modern society. While it might demonstrate technological advance and innovation, it is simply a prototype for ideas that demand integration into a broader and balanced design that should be more commonly practiced.

Cost is usually an important factor in building procurement, and a high construction price may well preclude the pursuit of sustainability during design. Yet the costs of buildings can be many times greater when measured over their life, and there is opportunity that good architecture can contribute to lower operational costs even in cases where the initial cost is higher. The technique of life cycle costing (LCC) is able to express buildings costs over many years into a comparable figure today, enabling decisions concerning future value to be more objective. Good architecture cannot divorce itself from the financial implications of acquisition and maintenance else it will be rendered ineffective in the practical realm.

The aim in this paper is to explore a method for measuring good architecture in terms of durability, adaptability and sustainability, and to derive a combined rating. This outcome should be reflected in examples of good architecture that we see around us. Using an analysis of 22 recent award-winning buildings in Southeast Queensland, Australia, the relationship between good architecture and the 3L Principle is tested. The LCC of projects (where cost data are available)can bemodelled to demonstrate how their cost profile is influenced by time. Such outcomes are compared to average LCC performance to determine if they represent superior financial performance. The research is significant in that it tests a process to objectively assess what is commonly intangible and determine if LCC is a suitable predictor of 'good architecture'. 


\section{What is good architecture?}

The identification of good architecture is a combination of multiple criteria that equate to values individuals may not agree upon. Vitruvius (circa 80-15 B.C.) insisted that three fundamentals should be present: function, structure, and beauty. Others might argue the relationship of a building with its surroundings, cultural context and society's expectations at the time are also important. Value for money might be added, based on cost-benefit evaluation that variously includes tangible and intangible components. Finally, Gordon's 3L Principle provides another lens through which good architecture can be viewed.As Frank Gehry put it: "architecture should speak of its time and place, but yearn for timelessness" (see http://en.wikiquote.org/wiki/Frank Gehry).

Of course, the question of what makes good architecture cannot be answered unequivocally. Nevertheless, just because a question has many answers does not mean that it should not be asked. In this paper, good architecture is evaluated in the context of durability, adaptability and sustainability. Each criterion is capable of objective measurement.

\section{Durability}

The ISO-15686 series on service life planning for buildings and constructed assets is a useful resource on building durability. However it is more applicable to building components and systems than entire buildings. The estimated service life of any component is calculated as its theoretical life multiplied by a series of factors that are each scored in the range 0.8 to $1.2(1=$ no impact). The factors comprise (a) quality of components, (b) design level, (c) work execution level, (d) indoor environment, (e) outdoor environment, (f) usage conditions, and (g) maintenance level. Whilst a building is a sum of the parts, such parts can be replaced and hence renewed, leaving the basic structure to determine overall life expectancy. Other literature on service life discusses the effect of external and internal actions on building durability, and principally identifies location, usage and design as the main parameters.

Obsolescence is the inability to satisfy increasing requirements or expectations (Iselin and Lemer, 1993; Lemer, 1996; Pinder and Wilkinson, 2000). This is an area under considerable stress due to changing social demand (Kintrea, 2007), and brings with it environmental consequences. Yet obsolescence does not mean defective performance. Douglas (2006) makes the further distinction between redundancy and obsolescence. The former means 'surplus to requirements', although this may be a consequence of obsolescence. Nutt et al. (1976:6) take the view that "... any factor that tends, over time, to reduce the ability or effectiveness of a building to meet the demands of its occupants, relative to other buildings in its class, will contribute towards the obsolescence of that building". A few researchers have included political changes to zoning, ascribed heritage classification and other imposed regulatory change also as a form of obsolescence (e.g. Campbell, 1996; Gardner, 1993; Luther, 1988; Kincaid, 2000).

To assist in the forecast of physical life in years, Langston (2011) developed an Excel calculation template. A series of questions gives insight into the longevity of a building according to three primary criteria: environmental context (location), occupational 
profile (usage) and structural integrity (design). Each category is equally weighted, and comprises ten questions requiring simple yes/no answers. Where information is unknown, blank answers are ignored in the calculation. Three questions under each primary criterion are double weighted due to their relative importance. Figure 1 presents the physical life calculator (adapted from Langston, 2011).

Some questions are worded so to deliver a positive score, while some are negative and others neutral (positive or negative). The type of question is distributed evenly throughout the template. The calculation algorithm assumes a base of 100 years and then adds or deducts points (years) according to the responses to questions. It is similar in concept to the Living to 100 Life Expectancy Calculator (see http://livingto100.com) that predicts human life span based on extensive medical and empirical data. But for buildings some conservatism is applied to the estimate and the forecast is rounded down to one of the following outcomes: $25,50,75,100,150,200,250$ or 300 years. The template is unsuitable for temporary structures or for iconic monuments that both require specialist judgment.

The construction of the calculator was informed from a broad survey of literature (unspecified), recent ISO-15686 standards and personal experience. It was founded on an adaptive management principle (Gregory et al., 2006; Linkov et al., 2006) that purports to develop a model and then evaluate its robustness through subsequent fieldtesting and observation. While the results of this testing appear promising, definitive validation arguably can only occur by comparison of estimates with reality, where the latter is measured as the duration of the building before its collapses. But as this is rarely witnessed, certainly through natural causes, field-testing and observation are the best validation methods available to us.

For the purposes of this research, the results of the physical life calculator are translated to a star rating as provided in Table 1.

Table 1: Durability star rating scheme

\begin{tabular}{|c|c|}
\hline Physical life (years) & Star rating \\
\hline 250 or above & 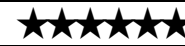 \\
\hline $200-249$ & 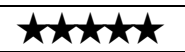 \\
\hline $150-199$ & 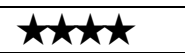 \\
\hline $100-149$ & 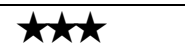 \\
\hline $75-99$ & $\star \star \star A$ \\
\hline $50-74$ & $\star$ \\
\hline below 50 & \\
\hline
\end{tabular}




\section{PHYSICAL LIFE CALCULATOR}

Bond University School of Sustainable Development

Framed roof structure with concrete floors. Masonry walls to ground and first level and half of second floor. Opening windows for natural ventilation. Large covered courtyard to north. Floor plate running east west with offices off central corridor. Stairs and lift to west.

y/n ?
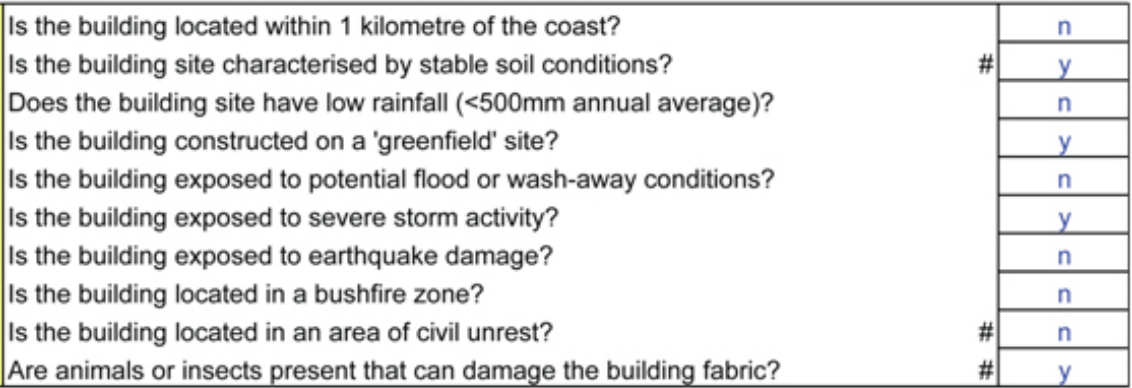

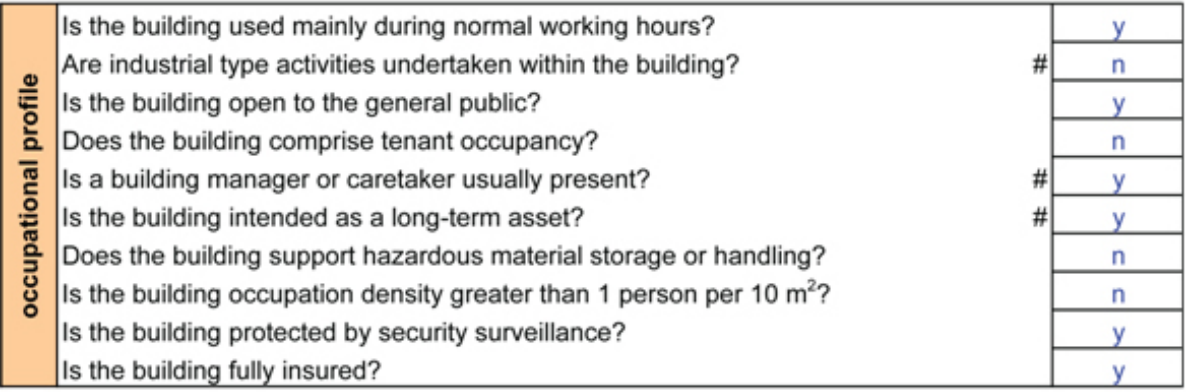

\begin{tabular}{|c|c|c|c|}
\hline \multirow{10}{*}{ 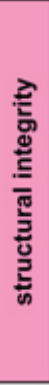 } & \multirow{10}{*}{$\begin{array}{l}\text { Is the building design typified by elements of massive construction? } \\
\text { Is the main structure of the building significantly over designed? } \\
\text { Is the building structure complex or unconventional? } \\
\text { Are building components intended to be highly durable? } \\
\text { Are there other structures immediately adjacent to the building? } \\
\text { Is the building founded on solid rock? } \\
\text { Was the workmanship standard for the project high? } \\
\text { Is the roof suspectible to leaking in bad weather conditions? } \\
\text { Is the building protected against accidental fire events? } \\
\text { Is the building designed as a public monument or landmark? }\end{array}$} & \multirow{5}{*}{ \# } & $\mathrm{n}$ \\
\hline & & & $\mathrm{n}$ \\
\hline & & & $\mathrm{n}$ \\
\hline & & & $\mathrm{n}$ \\
\hline & & & $\mathrm{n}$ \\
\hline & & \multirow[t]{2}{*}{$\#$} & $\mathrm{n}$ \\
\hline & & & $\mathrm{n}$ \\
\hline & & \multirow{3}{*}{$\#$} & $y$ \\
\hline & & & $y$ \\
\hline & & & \\
\hline
\end{tabular}

Notes:

Questions indicated (\#) are double weighted

Blank responses are ignored

Figure 1: Physical life calculator for Case Study \#2

$100 \%$ completed

\section{Adaptability}

For a wide range of reasons, buildings can become obsolete long before their physical life has come to an end. Investing in long-lived buildings may be sub-optimal if 
their useful life falls well short of their physical life. It is wise to design future buildings for change by making them more flexible yet with sufficient structural integrity to support alternative functional use. The development of a design-rating scheme for adaptation potential enables building designers to understand the long-term impacts of their decisions prior to construction, and thus enable optimisation for adaptive reuse to occur from the outset. As adaptive reuse potential already embodies financial, social and environmental criteria, the rating scheme would extend traditional operational considerations such as energy performance to include churn, retrofit, refurbishment and renewal considerations.

Atkinson (1988) modelled the process of obsolescence and renewal (of housing stock), and developed a 'sinking stack' theory to explain the phenomenon. Comparing total building stock over time produces a rising profile in total stock (accumulating via new construction each year) stratified according to building age (older buildings are at lower layers in the profile strata). New stock is added annually to the top of the stack. It degenerates over time and gradually sinks towards the bottom of the stack as new buildings are created and older ones demolished. If little new construction is added, then the entire building stock will age, and greater resources will be required to maintain overall quality and amenity levels. Certain layers in the stack are likely to represent periods of poor quality construction, and these layers age more rapidly and absorb greater maintenance resources (Ness and Atkinson 2001). Each layer in the stack reduces in height with the passage of time. Only the top layer grows because it represents the current rate of new construction. The net effect is a sinking of the stack, a phenomenon that occurs whether or not sufficient maintenance takes place.

Conejos (2013) developed adaptSTAR in an attempt to rate new building design for future 'adaptivity'. This rating is done normally when the project is in its design phase, although it can be applied in hindsight based on the latent conditions before a proposed intervention takes place. As such, it reflects the adaptability within a design concept that underpins the potential for change of functional use later in life.

The concept of the adaptSTAR design-rating scheme for adaptation potential was founded on the categories of obsolescence derived from literature. These comprised physical, economic, functional, technological, social, legal and political considerations (Conejos, 2013). Each category was broken down into sub-criteria that were also assembled from a review of the literature and from expert interviews with the design teams of eleven Australian award-winning adaptive reuse conversions in New South Wales and the Australian Capital Territory, as well as a pilot study involving the Melbourne General Post Office in Victoria. The sub-criteria were then rated by a sample of practising Australian architects experienced in adaptive reuse work in order to determine the relative importance of each sub-criterion, which then led to the weight of each respective obsolescence category being computed. The criterion weight is calculated from a five-point Likert scale (strongly disagree $=1$, disagree $=2$, neutral $=3$, agree $=4$, strongly agree $=5$ ).

The model can be applied using two approaches: either through a general ranking based on the main categories and their corresponding percentages, or by using the detailed ranking based on the design criteria. The latter is recommended. 
From this work it has been found that the seven obsolescence categories have reasonably equal weight. The coefficient of variation $(\mathrm{CoV})$ of the seven criteria weights was just $8.32 \%$. A scoring template was developed to enable new building design to be rated for future adaptation. This is illustrated in Figure 2 (adapted from Wilkinson et al., 2014). For the purposes of this research, the results of the adaptSTAR model are translated to a star rating as provided in Table 2 .

Table 2: Adaptability star rating scheme

\begin{tabular}{|l|l|}
\hline adaptSTAR score & Star rating \\
\hline 85 or above & $\star \star \star \star \star \star \star$ \\
\hline $75-84$ & $\star \star \star \star \star \star$ \\
\hline $65-74$ & $\star \star \star \star \star$ \\
\hline $55-64$ & $\star \star \star$ \\
\hline $45-54$ & $\star \star$ \\
\hline $35-44$ & $\star$ \\
\hline below 35 & \\
\hline
\end{tabular}

\section{Sustainability}

In Australia, the Green Building Council of Australia (GBCA, 2010) operates Australia's only national voluntary comprehensive environmental rating system for buildings, known as Green Star. The GBCA established Green Star as a rating system for evaluating the environmental design of buildings in 2002 and it evaluates the green attributes of building projects in eight categories (plus bonus points for innovation). The GBCA promotes green building programs, technologies, design practices and operations. Rating tools are currently available or in development for most building market segments, including commercial offices, retail, schools, universities, multi-unit residential buildings, industrial facilities and municipal buildings.

The goal of this rating system is to assess the current environmental potential (or sustainability) of buildings. It is a useful tool for property managers when identifying upgrade and retrofit priorities. The rating system also assists corporate sustainability and environmental reporting efforts. Every Green Star rating tool is organised into eight environmental impact categories and an innovation category. Credits are awarded within each of the categories, depending on a building's environmental performance and characteristics. Points are achieved when specified actions for each credit are successfully performed or demonstrated. Table 3 outlines the categories and normal weightings within the Green Star building rating system, although weightings can differ according to building type and location.

An environmental weighting is applied to each category score, which balances the inherent weighting that occurs through the differing number of points available in each category. The weights reflect issues of environmental importance for each state or territory of Australia and thus differ by region. The weighted category score is calculated as follows:

weighted category score $(\%)=$ category score $(\%) \times$ weighting factor $(\%) / 100$ 


\section{Bond University School of Sustainable Development}

When naminating your opinion to EACH of the following statements, please ossume thot the lotest adaptive reuse interventian has yet to occur. Your responses therefore relote to the lotent canditions BEFORE such intervention. Please rote ALL stotements using ONE opinian option and provide the key supporting REASON.

\begin{tabular}{|c|c|c|c|c|c|c|c|}
\hline How do you judge the following statements for the above building/tacility? & 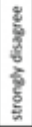 & $\begin{array}{l}\frac{8}{5} \\
\frac{6}{3} \\
\frac{3}{5}\end{array}$ & 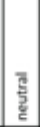 & 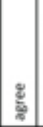 & 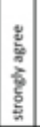 & What is the key reason that influenced your opinion? & 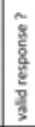 \\
\hline $\begin{array}{l}\text { The building's foundations and frame have capacity for additional structural loads } \\
\text { and potential vertical expansion. }\end{array}$ & & & & & & $\begin{array}{l}\text { Columns cannot be extended. Potential for light weight addition } \\
\text { to roof. }\end{array}$ & $\checkmark$ \\
\hline $\begin{array}{l}\text { The building fabric is well constructed using durable materials, providing potential } \\
\text { retention of existing exterior and interior finishes. }\end{array}$ & & & & & & $\begin{array}{l}\text { Concrete slabs and masonary walls. Timber showing aging and } \\
\text { steel sheeting showing damage (dents). }\end{array}$ & $\checkmark$ \\
\hline $\begin{array}{l}\text { The building currently has a low maintenance profile with modest expected levels } \\
\text { of component repair and replacement over its remaining lifespan. }\end{array}$ & & & & & & $\begin{array}{l}\text { Timber to exterior will require maintenance and possible } \\
\text { replacement. Extensive painted surfaces internally }\end{array}$ & $\checkmark$ \\
\hline $\begin{array}{l}\text { The building is situated in a bustling metropolis comprising mixed use development } \\
\text { and proximity to potential markets. }\end{array}$ & & & & & & Low rise urban area. & $\checkmark$ \\
\hline $\begin{array}{l}\text { The building is located near transport facilities and provides convenience for } \\
\text { vehicular and pedestrian mobility. }\end{array}$ & & & & & & Bus service available. Otherwise car and pedestrian only. & $\checkmark$ \\
\hline $\begin{array}{l}\text { The building enjoys a site with favourable plot size, access, topography, area, aspect } \\
\text { and surrounding views. }\end{array}$ & & & & & & Satisfactory site. Views are internalised to courtyard. & $\checkmark$ \\
\hline $\begin{array}{l}\text { The building's interior layout exhibits strong versatility for future alternative } \\
\text { arrangements without significant disruption or conversion cost. }\end{array}$ & & & & & & $\begin{array}{l}\text { A long thin floor plate with compartmentalised offices and } \\
\text { teaching rooms. }\end{array}$ & $\checkmark$ \\
\hline $\begin{array}{l}\text { The building has significant components or systems that support disassembly and } \\
\text { subsequent relocation or reuse. }\end{array}$ & & & & & & Awarded green star credit for this aspect. & $\checkmark$ \\
\hline $\begin{array}{l}\text { The building has sufficient internal open space and/or atria that provides } \\
\text { opportunity for spatial and structural transformations to be introduced. }\end{array}$ & & & & & & $\begin{array}{l}\text { Potential for external courtyard to be transformed but this would } \\
\text { affect the passive features of the building. }\end{array}$ & $\checkmark$ \\
\hline $\begin{array}{l}\text { The building has large floor plates and floor-to-floor heights with minimal } \\
\text { interruptions from the supporting structure. }\end{array}$ & & & & & & $\begin{array}{l}\text { Long thin floor plates with ceiling of approx. } 3.5 \mathrm{~m} \text { ground and first } \\
\text { floor. }\end{array}$ & $\checkmark$ \\
\hline $\begin{array}{l}\text { The building provides easy access to concealed ducts, service corridors and plant } \\
\text { room space to ensure effective horizontal and vertical circulation of services. }\end{array}$ & & & & & & Offices with grid cellings. & $\checkmark$ \\
\hline $\begin{array}{l}\text { The building is designed in such a way that it maximizes its orientation with good } \\
\text { potential for passive solar strategies. }\end{array}$ & & & & & & $\begin{array}{l}\text { Good access to daylighting and cross ventilation due to long } \\
\text { east/west access. }\end{array}$ & $\checkmark$ \\
\hline $\begin{array}{l}\text { The building has appropriate fenestration and sun shading devices consistent with } \\
\text { good thermal performance. }\end{array}$ & & & & & & Passive solar strategies well considered. & $\checkmark$ \\
\hline $\begin{array}{l}\text { The building has an insulated external envelope capable of ensuring good thermal } \\
\text { and acoustic performance for interior spaces. }\end{array}$ & & & & & & Thermal mass and separation of spaces. & $\checkmark$ \\
\hline $\begin{array}{l}\text { The building is designed in wars that maximize daylight use and natural ventilation } \\
\text { without significant mechanical intervention. }\end{array}$ & & & & & & Good passive strategies. & $\checkmark$ \\
\hline $\begin{array}{l}\text { The building has low energy demand and is operating at of readily capable of } \\
\text { achieving a 5-star Green Star* energy rating or equivalent. }\end{array}$ & & & & & & Green Star credits received. & $\checkmark$ \\
\hline $\begin{array}{l}\text { The building supports efficient operational and maintenance practices including } \\
\text { effective building management and control systems. }\end{array}$ & & & & & & BMS and user controls installed. & $\checkmark$ \\
\hline $\begin{array}{l}\text { The building has developed strong intrinsic heritage values, cultural connections or } \\
\text { positive public image over its life. }\end{array}$ & & & & & & $\begin{array}{l}\text { First } 6 \text { star Green Star for education. Building is used as an } \\
\text { eduational tool. }\end{array}$ & $\checkmark$ \\
\hline $\begin{array}{l}\text { The building has high architectural merit including pleasing aesthetics and } \\
\text { compatability with its surrounding streetscape. }\end{array}$ & & & & & & $\begin{array}{l}\text { Building sits well on the site and externally has pleasing aesthetics } \\
\text { using a simple palette of materials. }\end{array}$ & $\checkmark$ \\
\hline $\begin{array}{l}\text { The building provides relevant amenities and facilities within its neighbourhood that } \\
\text { can add value to the local community. }\end{array}$ & & & & & & Living lab and courtyard facilities. & $\checkmark$ \\
\hline $\begin{array}{l}\text { The building displays a high standard of construction and finish consistent with } \\
\text { current market expectations. }\end{array}$ & & & & & & Fit-out and finishing is standard. & $\checkmark$ \\
\hline $\begin{array}{l}\text { The building complies with current standards for fire prevention and sofety, } \\
\text { emergency egress and disability provisions. }\end{array}$ & & & & & & Recent bullding which complies with standards. & $\checkmark$ \\
\hline $\begin{array}{l}\text { The building offers an enhanced workplace emvironment that provides appropriate } \\
\text { user comfort, indoor air quality and environmental health and safety. }\end{array}$ & & & & & & $\begin{array}{l}\text { Passive strategies provide daylighting, user control for thermal } \\
\text { comfort and openable windows. }\end{array}$ & $\checkmark$ \\
\hline $\begin{array}{l}\text { The bullding's design is compatible with ecological sustainability objectives and } \\
\text { helps minimize ongoing habitat disturbance. }\end{array}$ & & & & & & Many environmental initiatives incorporated. & $\checkmark$ \\
\hline $\begin{array}{l}\text { The building displays a high level of community interest and political support for its } \\
\text { future care and preservation. }\end{array}$ & & & & & & $\begin{array}{l}\text { It is an important building due to being first } 6 \text { star Green Star for } \\
\text { education. }\end{array}$ & $\checkmark$ \\
\hline $\begin{array}{l}\text { The building's current or proposed future use conforms to existing masterplan, } \\
\text { zoning and related urban planning specifications. }\end{array}$ & & & & & & Education building on uniwersity campus. & $\checkmark$ \\
\hline
\end{tabular}

BUHREC Protocol Number R0-1208

74.17

Figure 2: adaptSTARscoring template for Case Study \#2

Note:In Case Study \#2, the adaptSTAR score of 74.17 comprised $11.50 \%$ physical, $10.83 \%$ economic, $10.51 \%$ functional, $20.02 \%$ technological, $15.49 \%$ social, $15.55 \%$ legal and $16.10 \%$ political criteria. 
Table 3: Green Star weightings (Yudelson, 2010)

\begin{tabular}{|l|l|}
\hline Environmental impact category & Weight \\
\hline Management & $10 \%$ \\
\hline Indoor environment quality & $20 \%$ \\
\hline Energy & $25 \%$ \\
\hline Transport & $10 \%$ \\
\hline Water & $12 \%$ \\
\hline Materials & $14 \%$ \\
\hline Land use and ecology & $4 \%$ \\
\hline Emissions & $5 \%$ \\
\hline
\end{tabular}

The sum of the weighted category scores, plus any innovation points, determines the project's rating. Only buildings that achieve a rating of four stars and above are certified by the GBCA.For the purposes of this research, the results of the Green Star checklist are translated to a star rating as provided in Table 4.

Table 4: Sustainability star rating scheme

\begin{tabular}{|c|c|}
\hline Green Star score & Star rating \\
\hline 75 or above & 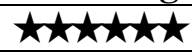 \\
\hline $60-74$ & 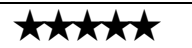 \\
\hline $45-59$ & $\star x t \lambda t$ \\
\hline $30-44$ & 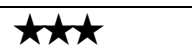 \\
\hline $20-29$ & $\star \star \star$ \\
\hline $10-19$ & $\star$ \\
\hline below 10 & \\
\hline
\end{tabular}

\section{Case Studies}

A web search of buildings in Southeast Queensland that have been recognised for a national, state or regional award for architectural excellence in the last ten years was conducted. The list was reduced to focus on public commercial and institution buildings, thus excluding homes and special purpose buildings or structures. It formed a heterogeneous sample including high-rise private apartment towers, specialist public infrastructure and simple low-rise market buildings.

It is proposed that award-winning buildings, as judged by experts from the architectural community, should demonstrate at least four stars in each of long life, loose fit and low energy criteria. Anecdotal evidence suggests that three stars might be considered normal. While other criteria most certainly should apply, these three should be considered as essential qualifications. As argued in the literature, they should be given equal weight.

Each case study was evaluated objectively using the methods described earlier in this paper. The raw scores were converted to a star rating. When a Green Star rating exists it was used, else a pseudo score was estimated. The final list of 22 buildings and their results are shown in Figure 3. Independent validation of the models' results by a panel of seven architectural experts drawn from local industry found there was $62 \%$ overall 
agreement. Photographic evidence to support the validation process was compiled during physical site visits that took place during 2014.

It is worth noting that there were only rare instances of buildings ( $4.5 \%$ of dataset) scoring less than four stars in any of the measured criteria. That suggests that the judging process for architectural awards appears consistent with Gordon's 3L Principle. The mean star rating across all 22 case studies was 5.09stars for durability $(\mathrm{CoV}=14.7 \%)$, 4.64stars for adaptability $(\mathrm{CoV}=14.2 \%)$, and 4.55 stars for sustainability $(\mathrm{CoV}=21.2 \%)$. A CoV of less than $20 \%$ represents low variability within the dataset. The mean overall rating for the case studies was 4.76 stars.

Should the minimum standard for architectural award be specified at five stars, then $39.4 \%$ of the dataset criteria would not qualify. Only 5 out of 22 projects in fact met or exceeded this higher threshold in each criterion. None of the case studies sourcedfrom Southeast Queensland over the last ten years scored six stars across the board.

\section{LCC Analysis}

LCC is defined as the total costs of acquisition, ownership and ultimate disposal over a building's existence. Comparing LCC per square metre requires both a common time horizon for the evaluation, and use of discounting to bring all costs into present value terms. LCC has been around since the 1960s, although the technique has its roots in engineering economics and can be traced back around 150 years.

Nevertheless, LCC data is rarely available, either due to no analysis being commissioned or for reasons of confidentiality. Only Case Study \#2 had an available estimate of LCC. Using a 30-year study period and a 3\% discount rate, the comparative LCC for this case studyin 2012 terms was AUS $\$ 6,536 / \mathrm{m}^{2}$ (Langston, 2013).

An earlier study based on 30 commercial buildings in Melbourne (Langston, 2006) found that the mean ratio of operating costs to capital costs equals 0.0361 per year.These buildings, which are examples of ordinary projects, had a mean capital cost of AUS\$ $2,540 / \mathrm{m}^{2}$ and a mean operating cost of AUS $\$ 4,175 / \mathrm{m}^{2}$ over 30 years (in 2006 terms). Adjusted to 2012, this equates to an LCC (capital + operating cost) of AUS $\$ 7,924 / \mathrm{m}^{2}$. Case Study \#2 has superior durability, adaptability and sustainability performance to the Melbourne data, and therefore suggests that good architecture may lead to lower LCC, albeit with potentially higher capital cost. Further investigation of this relationship is needed.

\section{Conclusions}

It can be concluded from this research that buildings that have recently been recognised for architectural excellence in Southeast Queensland portray the principles of long life, loose fit and low energy, and hence meet Gordon's 'test' for good architecture. His 3L Principle is expected to be inversely proportional to the computed LCC per square metre of gross floor area. Buildings with high star ratings for long life, loose fit and low energy, representing candidates for good architecture, should display a lower LCC profile when measured over a long time horizon (i.e. 30-100 years). This is because durability suggests both lower maintenance and replacement costs due to reduced decay, 


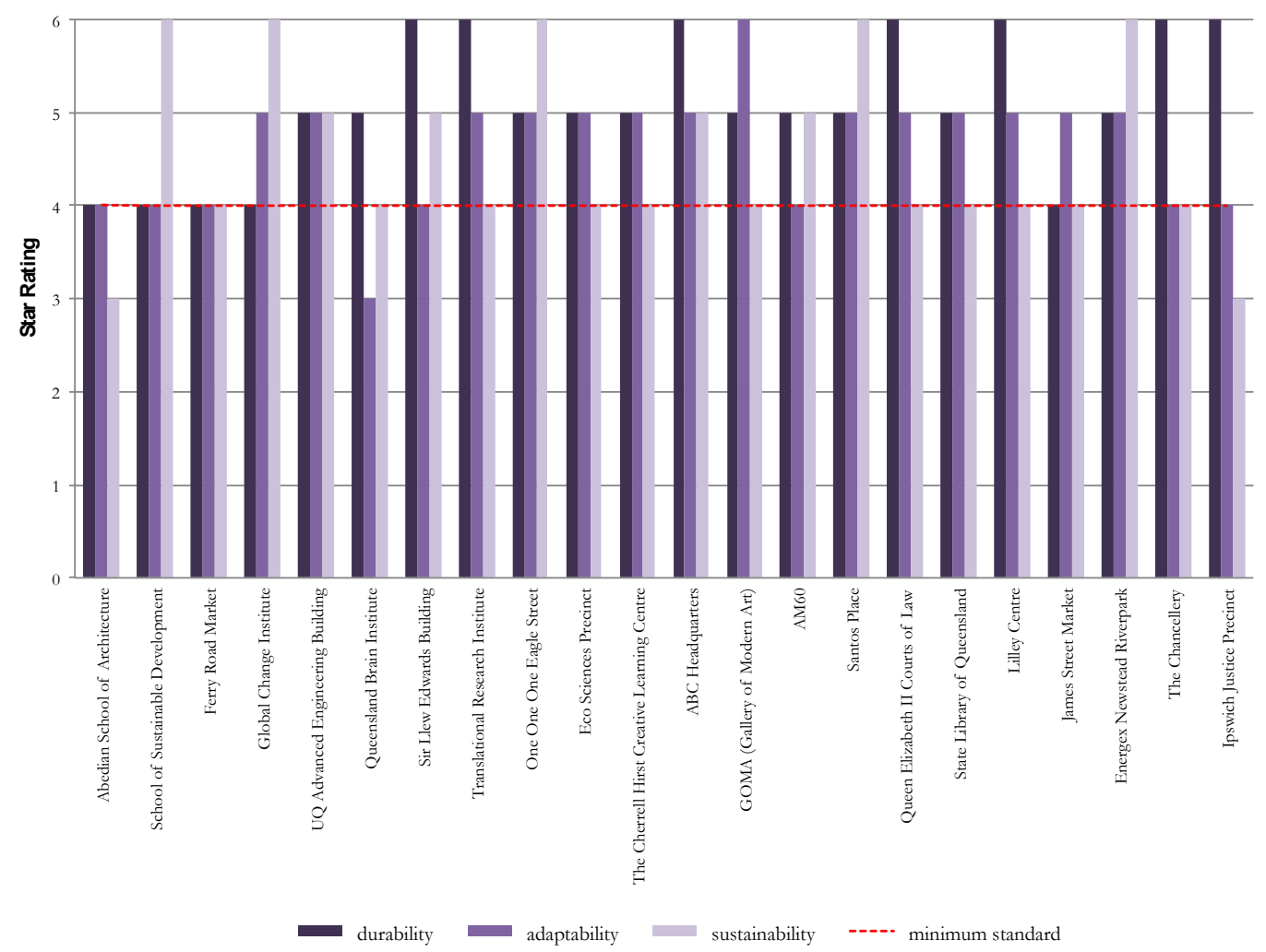

Figure 3: Case study summary

adaptability suggests both lower rates of churn and refurbishment costs arising from functional obsolescence, and sustainability suggests lower energy, water and other inputs through a more responsive environmental design. What might also be found, as this research agenda is pursued, is that good architecture leads to increased satisfaction, comfort and productivity for building occupants. Overall, sustainable development is enhanced when buildings meet longer-term design performance thresholds, avoiding premature and at times unnecessary destruction well before their true use-by date has been reached.

Sustainable development ideologically demands that architects design buildings that reflect long life, loose fit and low energy as a basic tenet. This research suggests that such strategy does not conflict with objectives to deliver 'good architecture', and may well lead to lower LCC values that make good architecture also good value. None of these matters should be considered mutually exclusive.

\section{References}

Atkinson, B. (1988) Urban ideals and the mechanism of renewal, in proceedings of RAIA Conference, June, Sydney.

Campbell, J. (1996) Is your building a candidate for adaptive reuse?,Journal of Property Management, 61(1), 2629. 
Conejos, S. (2013) Designing for future building adaptive reuse, PhD thesis, Bond University, Australia.

Douglas, J. (2006) Building adaptation (second edition), Butterworth-Heinemann.

Gardner, R. (1993) The opportunities and challenges posed by refurbishment, in proceedings of Building Science Forum of Australia, Sydney, 1-13.

Gordon, A. (1972) Designing for survival: the President introduces his long life/loose fit/low energy study, Royal Institute of British Architects Journal, 79(9) 374-376.

GBCA (2010) What is Green Star?, available at: http://www.gbca.org.au/green-star/green-star-overview/, (accessed 19/02/2010).

Gregory, R., Failing, L. and Higgins, P. (2006) Adaptive management and environmental decision making: a case study application to water use planning, Ecological Economics, 58(2), 434-447.

Iselin, D.G. and Lemer, A.C. eds. (1993) The fourth dimension in building: strategies for minimizing obsolescence, Committee on Facility Design to Minimize Premature Obsolescence, Building Research Board, Washington DC: National Academy Press.

Jacobs, J. (1961) The death and life of great American cities, Random House.

Kincaid, D. (2000) Adaptability potentials for buildings and infrastructure in sustainable cities, Facilities, 18(3/4), 155-161.

Kintrea, K. (2007) Housing aspirations and obsolescence: understanding the relationship, Journal of Housing and the Built Environment, 22, 321-338.

Langston, Y.L. (2006) Embodied energy modelling of individual buildings in Melbourne: the inherent energy-cost relationship, $\mathrm{PhD}$ thesis, Deakin University, Australia.

Langston, C. (2011) Estimating the useful life of buildings, in proceedings of AUBEA2011 Conference, Gold Coast, Australia, April, 418-432.

Langston, C. (2013) The role of coordinate-based decision-making in the evaluation of sustainable built environments, Construction Management and Economics, 31(1), 62-77.

Lemer, A.C. (1996) Infrastructure obsolescence and design service life, Journal of Infrastructure Systems, 2(4), 153-161.

Linkov, I., Satterstrom, F.K., Kiker, G., Batchelor, C., Bridges, T. and Ferguson, E. (2006) From comparative risk assessment to multi-criteria decision analysis and adaptive management: recent developments and applications, Environment International, 32(8), 1072-1093.

Luther J.P. (1988) Site and situation: the context of adaptive reuse, in Adaptive reuse: issues and case studies in building preservation, R. Austin ed., Van Nostrand Reinhold, 48-60.

Murray, G. (2011) Stirling Prize analysis: long life, loose fit, low energy, e-Architect Newsletter article \#125, available online at http://www.e-architect.co.uk/articles/persistence-of-the-absurd (accessed 20/06/14).

Ness, D. and Atkinson, B. (2001) Re-use/upgrading of existing building stock, BDP Environment Design Guide, Building Design Professions, Canberra.

Nutt, B., Walker, B., Holliday, S. and Sears, D. (1976) Housing obsolescence, Hants: Saxon House.

Pinder, J. and Wilkinson, S.J. (2000) Measuring the gap: a user based study of building obsolescence in office property, The Cutting Edge 2000, London: RICS Research Foundation.

Wilkinson, S.J., Remøy, H. and Langston, C. (2014) Sustainable building adaptation: innovations in decision-making, Wiley Blackwell.

Yudelson, J. (2010) Greening existing buildings, McGraw Hill Companies, Inc. 